\title{
The consequences of increasing assertiveness of trans-national religious communities for international relations
}

\author{
Najamudin \\ STAI LaTansa Mashiro Rangkasbitung Banten \\ E-mail:najamudin.76@gmail.com
}

\begin{abstract}
The transnational communities, or in other terms, the migrant communities who went to the US and the UK, or to any other European states had strong belief in their religion in which they might not be contaminated by the secular ideology in the Western countries. In this respect, the phenomenology of religion in international relations is a relatively new and surprising. Accordingly, this paper aims at investigating the implications of the emergence of trans-national religious groups for international relations. The paper will argue that the rise of trans-national religious groups has produced a profound impact on international relations. The factors that influenced this transformation in international relations is the contemporary processes of globalization which scholars argue, are pivotal to bringing religion to the centre stage of international relations. In order to deepen the understanding of this process, two case scenarios will be analyzed, namely, the Sikh Diasporas and the imagined Islamic community, the umma. In this paper, it has been argued that the rise of trans-national religious actors may affect state sovereignty in one way or another. Under secular ideology, the role of religion is marginalized from the public sphere, in particular, the domain of politics and
\end{abstract}


religion is being obviously separated. This separation, according to both groups, is problematic. It is therefore, the emergence of Islamic and Sikh communities is considered by some liberal democratic countries like India as a peril to its state sovereignty. In Islamic doctrines, the Muslims hold a principle in din wa dawla, the unity of state and religion, while in Sikhism, the Sikhs have to trust miri and piri, the unification of religious and political institution.

Masyarakat transnasional atau dalam terma lain disebut juga sebagai masyarakat migran yang menetap di Amerika dan Inggris, atau ke negara-negara Eropa lainnya memiliki keyakinan yang kuat terhadap agama mereka dan tidak terkontaminasi oleh ideologi sekuler Barat. Pada konteks ini, fenomenologi agama dalam perspektif hubungan internasional merupakan kajian baru dan menarik untuk dibahas. Berdasarkan hal tersebut, makalah ini bertujuan untuk menyelidiki implikasi dari munculnya kelompok trans-nasional tersebut terhadap kajian hubungan internasional. Makalah ini berasumsi bahwa munculnya kelompok sosial keagamaan yang bersifat trans-nasional berdampak besar terhadap hubungan internasional. Faktor-faktor yang mempengaruhi perubahan ini adalah proses globalisasi yang menarik agama ke dalam pola hubungan internasional. Untuk lebih jelasnya, dua skenario kasus akan dianalisis, yaitu Diaspora Sikh dan konsepsi 'keummatan' dalam Islam. Dalam pembahasan makalah ini, didapati bahwa munculnya kelompok masyarakat trans-nasional dapat mengancam kedaulatan suatu negara dalam berbagai bentuknya. Dalam ideologi sekuler, peran agama termarjinalkan dari ruang publik, khususnya ranah politik. Pemisahan ini, menurut kedua kelompok tersebut, memiliki sejumlah permasalahan. Oleh karena itu, munculnya masyarakat transnasional Islam dan Sikh dianggap oleh beberapa negara demokrasi liberal seperti India sebagai ancaman bagi kedaulatan negara. Dalam perspektif Islam, prinsip din wa dawlah merupakan konsepsi kesatuan negara dan agama, sementara dalam ajaran Sikhisme, doktrin miri piri, merupakan konsepsi penyatuan lembaga keagamaan dan politik.

\section{Keywords: Transnational religious groups; Sikh diaspora; Umma; State sovereignty}

\section{Introduction}

This study focuses on how trans-national religious communities have emerged as a critical juncture in reforming a new feature of interna- 
tional politics. Religion along with its systems of belief was not only having no significant role in international politics for many years, but also being separated from the study of statecraft. The 1648 Westphalia treaty had been a point of departure for establishing the idea of secularism in European countries; that is, restricting the function of religion within the state. ${ }^{1}$ This restriction did not stay any longer until the late of the $20^{\text {th }}$ century. Religion, nonetheless, begun to involve in state politics in many ways, and hence, had been effective means to express religious symbols and aspirations. The transnational communities, or in other terms, the migrant communities who went to the US and the UK, or to any other European states had strong belief in their religion in which they might not be contaminated by the secular ideology in the Western countries. In this respect, the phenomenology of religion in international relations is a relatively new and surprising.

The post-Westphalia international politics takes into consideration the vital role of state sovereignty, unchallenged until the arrival of globalization in the 1980 s. $^{2}$ Globalization, nevertheless, has generated new socio-political spectrum for transnational actors as well as challenges for the state and its citizens alike. In this sense, the transnational actors have benefited from globalization to advance the cause of deterritorialized religious nationalism. ${ }^{3}$ Accordingly, the globalization process of 1980 s connected with the change of economic, social and political domains is resulted from the rise of a global social space, where

${ }^{1}$ Scott M.Thomas, The Global Resurgence of Religion and the Transformation of International Relations: The Struggle for the Soul of the Twenty-First Century, New York: Palgrave MacMillan, 2005, 33.

2]. Haynes, An Introduction to International Relations and Religion, Harlow, Essex: Pearson Longman, 2007, 31.

${ }^{3}$ Scott M. Thomas, The Global Resurgence of Religion and the Transformation of International Relations: The Struggle for the Soul of the Twenty-First Century. New York: Palgrave MacMillan, 2005, 29. 
borderless interactions and interdependencies develop between persons. ${ }^{4}$ On this level, there is a strive between the forces of globalization and the local assertions of identity and culture. The space for ethnicity in world politics is being contested as a matter of right by the diasporic ethnicity. In short, the globalization process as a main force of impact affects the new politics of space, culture and identity of diasporic communities as the embodiment of the post modern world. ${ }^{5}$

In addition, the transnational civil society, in its new face, consists of individuals, groups and organizations in different countries that work together across borders in pursuance of common goals. ${ }^{6}$ In line with this, religious affiliations provide a connection to homogenous religious groups and sentimental resources to people who adhere to religiopolitical community and an identity they can take pride in. ${ }^{7}$ At the same time, the new sociopolitical forms of engagement brought about by the slow transformation of the old into the new have redefined the social and political conventions associated with the nation-state. ${ }^{8}$ The new order has undermined many of the traditional pillars of a secular nationstate. In short, the concepts like national sovereignty, economic autonomy, and socio-religious identity have all undergone changes. In the light of these changes, the paper will analyze the ever-changing genre of relationship between the state and the transnational religious groups producing a profound change in international relations.

${ }^{4}$ L. Gayer, The Globalization of Identity Politics: The Sikh Experience. May, 2002, 2 available from <http://www.ceri-sciences-po.org> , accessed on 2 April 2009.

${ }^{5} \mathrm{~L}$. Gayer, The Globalization of Identity Politics..., 3.

${ }^{6} \mathrm{~J}$. Haynes, An Introduction to International Relations and Religion, Harlow, Essex: Pearson Longman, 2007, 47.

${ }^{7} \mathrm{G}$. Shani, "A Revolt against the West: Politicized Religion and the International Order-A Comparison of the Islamic Umma and the Sikh Qaum", Ritsumeikan Annual Review of International Studies, Vol.1 (2002), 29.

8]. Samuel Barkin and Bruce Cronin, "The State and the Nation: Changing Norms and the Rules of Sovereignty in International Relations", International Organization, Vol.48, No.1 (1994), 110. 
This paper aims at investigating the implications of the emergence of trans-national religious groups for international relations. The paper will argue that the rise of transnational religious groups has produced a profound impact on international relations. The factors that influenced this transformation in international relations is the contemporary processes of globalization which scholars argue, are pivotal to bringing religion to the centre stage of international relations. ${ }^{9}$ In order to deepen the understanding of this process, two case scenarios will be analyzed, both are the uniqueness of Sikh Diasporas and the rise of a so-called imagined Islamic community, the umma. In the paper, it has been argued that the rise of trans-national religious actors may affect state sovereignty in one way or another.

This paper is outlined in three parts. In the first part, clarification of some definitional issues regarding the topic is presented. Next, some literatures will be reviewed, followed by questioning the rationale behind the rise of trans-national religious group on the global level. Afterwards, two case studies are discussed and analyzed, and the last is conclusion.

\section{Transnational actors: some definitional aspects}

By way of classification, according to Scott M. Thomas, there are three kinds of religious non-state actors namely sub-state actors, transnational actor, and inter-governmental organizations. ${ }^{10}$

First is a sub-sate actor. In Thomas' view, sub-state actors may be called sub-national actors work as local interest groups or the ones who sometimes pressure the government in a state on the purpose of

${ }^{9} \mathrm{~F}$. Petito and P. Hatzopoulos. Religion in International Relations: Towards a De-secularised Transnational Civil Society? The Return from Exile, New York: Palgrave, 2003.

${ }^{10} \mathrm{Scott}$ M. Thomas, The Global Resurgence of Religion and the Transformation of International Relations: The Struggle for the Soul of the Twenty-First Century, New York: Palgrave MacMillan, 2005, 99-105. 
having influence on its national or international policy. In the West, these groups are under big and legal institutions representing religious diversity on the local level. In terms of its resource mobilization, they get a huge amount of funding from variety of sources such as government, international donations, and so on; it depends on the link between the church and the state. To mention but some, Catholic Bishops' Conference in England or Wales, Evangelical Alliance in the UK, Jews Board of Deputies in England, or Muslim Council in Great Britain are evident in this category. ${ }^{11}$

The second type is trans-national actors. This group of people, as Thomas observes, are out of state's control either by its policy in national or international level or event by international institutions albeit they are closely connected with international links. ${ }^{12}$ Based on their interests, this group can be separated into two forms notably profit oriented companies like MNCs or multinational corporations, and nonprofit oriented organizations such as Non-Government organizations or NGOs. All religious NGOs are included in non-profit organizations For instance, Oxfam, a Methodist minister, a Jewish Rabbi, and CARE which was established by American Quakers. ${ }^{13}$

The last category is Inter-Governmental Organizations (IGOs). Well known as a kind of international organizations, the members of IGOs are local governments. With regards to their functions, IGOs can be either nationally or regionally linked such as Arab leagues, the European Union, WTO, and NATO. By comparison, some religious IGOs are distinct in character. For example, the Organization of the Islamic Con-

${ }^{11}$ Scott M. Thomas, The Global Resurgence of Religion and the Transformation of International Relations: The Struggle for the Soul of the Twenty-First Century, New York: Palgrave MacMillan, 2005, 99.

${ }^{12}$ Scott M. Thomas, The Global Resurgence of Religion..., 100.

${ }^{13}$ Scott M. Thomas, The Global Resurgence of Religion..., 101. 
ference (OIC) recruits its members on the basis of religions not states, and envisions its members the notion of establishing the Umma to unify Islamic community beyond its state boundaries. ${ }^{14}$

By definition, a transnational religious actor, as suggested by Shani, could be considered as a non-governmental individual or a group with specific religious affiliations having connections with an actor in another country or with an international organization. ${ }^{15}$ In addition, Haynes observes that this group is intended to affect international politics using a so-called soft power which in Joseph Nye's opinion prone to be direct and often cultural or ideological influences and encouragement. ${ }^{16}$

\section{The rise of transnational religious actors: a threat to state sovereignty?}

Transnational religious actors, once having founded in position of its impact, tend to mobilize themselves as a global transnational civil society. In Lipschultz's view, a transnational civil society is as a consequence of a self-conscious construction of networks of knowledge and action, by decentred, local actors, that cross the reified boundaries of space as though they were not there. ${ }^{17}$ In many ways, a globalized transnational civil society, as suggested by Shani, has a strong connection among its members of non-state actors albeit they are from various religious backgrounds because they share commonalities in terms of economical or political interests to assist each others to face the

${ }^{14}$ Scott M. Thomas, The Global Resurgence of Religion..., 103-104.

${ }^{15} \mathrm{G}$. Shani, Towards a De-secularized Transnational Civil Society? Transnational Religious Actors and International Relations, 2007, 8. Paper presented at panel on 'Religion, Soft power and International Relations', SGIR Conference, Torino, September, 12-15 2007. available from <http://archive.sgir.eu/uploads/Shani-sgir_2007_(shani).pdf> accessed on 2 April 2009.

${ }^{16} \mathrm{Haynes}$, An Introduction to International Relations and Religion, Harlow, Essex: Pearson Longman, 2007, 40.

${ }^{17}$ R. Lipschultz, "Reconstructing World Politics: The Emergence of Global Civil Society", Millennium, Vol. 21, No. 3 (1992), 390. 
wave of secularism. ${ }^{18}$ In Gramscian perspective, as cited by Shani, such a construct of civil society may be considered as counter-hegemonic because this can be another option to the idea of a secularized liberal model of global civil society. ${ }^{19}$

The transnational religious groups, even though living as 'migrant citizens or non-citizens' such as British born Pakistan or India are subject to national policy in the country of residence, but at the same time they are connected with some religious allegiances along with political tendency to certain ethnic community outside of the state territory. Sikhism, for example, is a good case in this point. The concept of transnationalism, according to Mirdal, tends to be suprastatal memberships, identities and loyalties, a condition beyond the usual state-bound national identities. ${ }^{20}$ Accordingly, in terms of its socio-cultural dynamics, transnationalism mirrors social, cultural, and economic links which are between, above or beyond the nation state..$^{21}$ Trans-nationalism, hence, as process which has resulted in increasing contacts among people on the global scale. As a consequence, trans-migrants shaping their identities in the countries they live in are automatically and naturally affected by norms and values from their countries of origin as well as the environment of their countries of residence. In this sense, it is obvious

\footnotetext{
${ }^{18} \mathrm{G}$. Shani, Towards a De-secularized Transnational Civil Society? Transnational Religious Actors and International Relations, 2007, 7. Paper presented at panel on 'Religion, Soft power and International Relations', SGIR Conference, Torino, September, 12-15 2007.available from <http://archive.sgir.eu/uploads/Shani-sgir_2007_(shani).pdf> accessed on 2 April 2009.

${ }^{19}$ M. Kaldor, Global Civil Society: An Answer to War, Cambridge: Polity, 2003, cited in G. Shani, "Towards a De-secularized Transnational Civil Society? Transnational Religious Actors and International Relations", 2007, 8, paper presented at panel on 'Religion, Soft power and International Relations', SGIR Conference, Torino, September, 12-15, 2007, available from <http:// archive.sgir.eu/uploads/Shani-sgir_2007_(shani).pdf>, accessed on 2 April 2009.

${ }^{20} \mathrm{G}$. Mirdal and L. Ryynanen-Karjalainen M, Migration and Trans-cultural Identities, European Science Foundation (ESF) Forward Look Report 2 (2004), 7.

${ }^{21}$ R. Grillo, "Islam and Trans-nationalism", Journal of Ethnic and Migration Studies, Vol. 30, No. 5 (2004).
} 
that globalization in many ways affect people and their construction of identity in terms of culture, ways of life, world views, and faith.

According to Haynes, trans-national actors, either religious or nonreligious ones, are suspected to affect state sovereignty. By this he means a state independence from overt interference by another state or states.22 Quoting Philpott, Haynes observes that the discourse on sovereignty in the study of international relations is almost missing due to its excessive focus on the notion of secularism. Haynes gives a very good example of the relations between Islam and Christianity long before the improvement of the current international system. He argues that the phenomenology of religious transnational movement nowadays is not 'de novo' but has its vital historical roots. ${ }^{23}$

Consider this example. Dating back to the seventh century, Islam was born in Arabian Peninsula, expanded successfully to other regions such as Africa, Asia, and Europe (including Balkans and Iberian areas) to establish a sort of pan-Islamism, the umma, that is an imagined Islamic global society. In the process of its rapid expansion, Islam was challenged by unified European countries and failed to exist as an Islamic empire within the European states. ${ }^{24}$ In this respect, the state sovereignty of European polities was actually in peril due to the rise of the umma albeit it did not succeed in imposing its religious governmental system namely sharia.

\footnotetext{
22]. Haynes, An Introduction to International Relations and Religion, Harlow, Essex: Pearson Longman, 2007, 128.

${ }^{23} \mathrm{D}$. Philpott, "The Challenge of September 11 to Secularism in International Relations", World Politics 55 (2002), 66-95, cited in J. Haynes, An Introduction to International Relations and Religion, Harlow, Essex: Pearson Longman, 2007, 129.

24]. Haynes, An Introduction to International Relations and Religion, Harlow, Essex: Pearson Longman, 2007, 129.
} 
By contrast, different from the umma, Christendom tells another story. In the light of history, Christendom is considered 'no longer exists. ${ }^{25}$ In the early period of Christianity, Christendom was deemed as a general theory of 'universal norms and laws' stemmed from God which was becoming fundamental doctrines of just war theories. ${ }^{26}$ In its development, around sixteenth century, the trans-national widespread of Christianity was brought by Spanish and Portuguese conquerors in search for gold and natural resources from South America to the Caribbean and some countries in Asia. In short, Christendom was mainly associated with European expansion through the foundation of European colonies. While religion has been marginalized from the public sphere in Europe and other countries, international relations have been improved in the way the global order was formed and mixed by other secular ideologies like nationalism, communism, and liberal democracy. ${ }^{27}$

However, in his analysis, Haynes does not clarify the hazards of the so-called transnational religious actors for state sovereignty of a country like Europe in detail. ${ }^{28}$ Two case studies provided, the Umma and Christendom, denotes only the significance of historical facts regarding the issue of state sovereignty in international relations. Here, two important questions emerge: Are all transnational religious actors potentially harming state sovereignty? How do transnational religious actors

${ }^{25}$ B. Lewis, "The Roots of Muslim Rage", The Atlantic Monthly (September 1990), 52-60 cited in J. Haynes, An Introduction to International Relations and Religion, Harlow, Essex: Pearson Longman, 2007, 129-130.

${ }^{26} \mathrm{C}$. Dolan, In War We Trust: The Bush Doctrine and the Pursuits of Just War, Aldershot: Ashgate, 2005, cited in J. Haynes, An Introduction to International Relations and Religion, Harlow, Essex: Pearson Longman, 2007, 129.

${ }^{27} \mathrm{~J}$. Haynes, An Introduction to International Relations and Religion, Harlow, Essex: Pearson Longman, 2007, 129-130.

28]. Haynes, An Introduction to International Relations..., 130. 
endanger state sovereignty of a country? To answer these questions, some theories of state sovereignty are needed, followed by comparative analysis of two other case studies: the imagined Umma and the Sikh Diaspora.

Quoting Weber's definition, Barkin and Cronin see sovereignty within the study of international relations in two distinctive features of entities: state sovereignty and nation sovereignty. ${ }^{29}$ While state sovereignty is associated with the border lines of a countries upon which have to be controlled by the legitimate governments, nation sovereignty is considered as communities of sentiment forging the political lines of an authoritative state. Here, the difference between sovereignty of states and nations seems obvious using this theoretical framework. Nonetheless, on the perspective of liberal interdependence literature, there are, at least, three obstacles regarding this basic theory. ${ }^{30}$

First is the problem of state control. According to Thomson, sovereignty is basically not about state control, but about state authority. ${ }^{31}$ Correspondingly, Thomson poses a provocative question concerning this issue stating that

"...whether or not the state's ability to make authoritative political decisions has eroded; that is, whether ultimate political authority has shifted from the state to non-state actors or institutions". ${ }^{32}$

In other questions, does a state have a legitimate authority to control trans-national religious actors in this category? Put it simply, do

29]. Samuel Barkin and Bruce Cronin, "The State and the Nation: Changing Norms and the Rules of Sovereignty in International Relations", International Organization, Vol. 48, No.1 (1994), 110-111.

${ }^{30}$ Janice E. Thomson, "State Sovereignty in International Relations: Bridging the Gap between theory and Empirical Research", International Studies Quarterly, Vol. 39 (1995), 216.

${ }^{31}$ Janice E. Thomson, "State Sovereignty in International Relations ..., 216.

${ }^{32}$ Scott M. Thomas, The Global Resurgence of Religion and the Transformation of International Relations: The Struggle for the Soul of the Twenty-First Century, New York: Palgrave MacMillan, 2005, 216. 
trans-national religious actors really endanger state sovereignty? If so, in what way?

The second problem is about a criterion of functionalism. Under this category, the state and sovereignty are responsible to serve societal needs like economic growth and protection from military attack. ${ }^{33} \mathrm{Nev}-$ ertheless, there are a few literatures to strengthen this view. As a matter of fact, to mention some, study by Strayer, Tilly or Gidden emphasizes that the state's function is to wage a war and to build power against other states and society. ${ }^{34}$ In response with this, Thomas objects that

"... it is a-historical to suggest that states are losing control, that sovereignty is eroding, because states cannot now fulfill functions they never had, or have assumed only recently". ${ }^{35}$

If so, what about a state policy regarding the rise of Islamic fundamentalism in pursuits of Islamic umma? In other words, is this policy intended to protect citizens of a state from military attacks of militant Islam? I take it as a challenge to this liberal interdependence view on relations between state and sovereignty in accordance with the issue of Islamic radicalism and terrorism.

The last is about a logical explanation on the links between sovereignty and interdependence. There are no clear arguments to support regarding this issue. Instead, Thomson asks

"...Is increasing interdependence the cause of declining sovereignty or vise versa? That is, are interdependence linkages reducing the state's ability to control its borders, or is the state's declining ability

${ }^{33}$ Janice E. Thomson, "State Sovereignty in International Relations..., 216.

${ }^{34}$ Strayer, 1970, cited in Janice E. Thomson, "State Sovereignty in International Relations: Bridging the Gap between theory and Empirical Research", International Studies Quarterly, Vol. 39 (1995), 216.

35Janice E. Thomson, "State Sovereignty in International Relations: Bridging the Gap between theory and Empirical Research", International Studies Quarterly, Vol. 39 (1995), 216. 
to control its borders, presumably due to technological developments, facilitating the proliferation of ties of interdependence? ? $^{136}$

In the case of Sikh Diaspora, this problem is significant to clarify. For instance, is there a strong connection between, say, British sovereignty and interdependence of Sikhs in the UK and in the Punjab as their homeland? To be precise, will the increase of Sikhs' interdependence decline British sovereignty or vise versa? The answer to this obstacle seems not clear too.

\section{The imagined umma and the Sikh diaspora}

Transnational religious actors function as an external force on state sovereignty, and its global aspects provide claims and counterclaims of empowerment of the immigrant communities. The case studies on the imagined Umma and the Sikh Diaspora will provide credence to the analysis of transnational religious groups' resurgence on the international political scene. These two case studies are supposed to answer some of the questions raised and then further to investigate if these two case scenarios support the hypothesis that transnational religious groups, indeed, have affected the international relations. These two cases will also be analyzed if the rise of trans-national religious actors influence state sovereignty or not.

Imagined umma: Islamic unity versus state sovereignty

Umma is an Arabic vocabulary, meaning, a community of believers. This term has something in common with Hebrew, that is, 'am' or people, which according to Halliday both are derived from the same roots of 'Aramaic and 'Akkadian. ${ }^{37}$ It is also mentioned many times,

\footnotetext{
36]anice E. Thomson, "State Sovereignty in International Relations"..., 216.

${ }^{37}$ Fred Halliday, "The Politics of the Umma: States and Community in Islamic Movements", Mediterranean Politics, Vol.7, No.3 (2002), 23.
} 
approximately 62 times, in the Quran, a Muslims' holy book, and often cited in the Hadith, the Prophet Muhammad's sayings and traditions. In the course of Islamic history, this word had been associated with the notion of 'khulafa' or 'successors,' in the early period of Islamic empire up until the fall of the Caliphate, an Islamic governmental system, in $1924 .{ }^{38}$ In the recent time, it has been connected to the imagination of creating 'khilafa' or a sort of Islamic state based on shari'a or Islamic laws. Borrowing Benedict Anderson's terminology, Imagined Community, in this paper, I would call umma as an Imagined Islamic community, that is, a faithful community the Muslims have in mind to emerge someday. ${ }^{39}$

In its broader sense, the term umma may also be meant diversities for two arguments. First, referring to Islamic story, it did not necessarily reflect a mere Islamic term regarding system of belief, but it was also a sort of constitution managing religious diversities where Jews in Medina in the time of the Prophet Muhammad were under protection of Islamic empire. Second, the issue of plurality and diversity are mentioned in the Quran in Sura or chapter 10:9 "People were once a single umma, but they differed", followed by "I created peoples and tribes so that they should get to know each other".40

In the early Islamic period, it was in the Prophet Muhammad's life time, the term umma was used to describe the people of Madina including Muslims, Jews, and Pagan under Islamic government, but then it was limited to Muslim community only. By contrast, in the light of traditional Islamic literature, the so-called umma was deemed both

\footnotetext{
${ }^{38}$ Fred Halliday, "The Politics of the Umma"..., 23.

${ }^{39}$ Benedict Anderson, Imagined Communities: Reflections on the Origin and Spread of Nationalism, revised edition. 1st ed. 1983. London: Verso, 1991.

${ }^{40}$ Fred Halliday, "The Politics of the Umma"..., 24.
} 
in positive and negative impression; it related to either religious or tribal groups. In addition, in the early medieval time, the term then comprised social status or other groups of people, albeit it connoted immensely the 'Arab nation. ${ }^{41}$

In the next development of umma, for hundreds of years, it had been articulated in two forms of Islamic polity namely the caliphate and the sultanate, particularly in the Middle East and North Africa. Even though religious doctrines were not intended to manage Islamic laws with politics, or precisely to distinguish between religion and politics, some theories of politics proposed by ulama or Islamic scholars justified the forms of Islamic empire like the caliphate and the sultanate. Ironically, they were often waging wars against each others. ${ }^{42}$

It was around the nineteenth century, the notion of umma had been developed as modern political community. According to Jamal alDin al-Afghani, a proponent of Islamic revival and Moslem politician devoted to work in the Ottoman empire, in Egypt and Iran, umma in modern age should be seen as a nation like any other modern countries such as the UK, France, and Germany. Al-Afghani is convinced in unifying Muslims all over the word under one Islamic polity in order to achieve a revival of Islamic civilization and a restoration of the essential solidarity, ta'asub, which binds all communities together. ${ }^{43}$

From this period onwards, the meaning of umma had been changing over the time depending on its context. It could be either Muslim community as a whole or as a part like Arabs, Egyptians, or any other countries in the Middle East. As a result, there has been a mixture between religious terms and borders in defining umma. Take for in-

${ }^{41}$ G.P. Makris, Islam in the Middle East: a Living tradition, USA: Blackwell Publishing, 2007, 45.

${ }^{42}$ G.P. Makris, Islam in the Middle East..., 45.

43Jamal al-Din al-Afghani (1839-1897) and Hourani, 1962:107-129, cited in Fred Halliday, "The Politics of the Umma"..., 26. 
stance, Husain al-Marsafi, the Professor of al-Azhar Islamic University Cairo, wrote a book entitled "Risalat al-Kalim al-Thaman," (Tract on Eight Words), and he considered umma as a community determined not only by faith but also by territory and language. ${ }^{44}$

In spite of its various meanings of umma, Muslims all over the world are inspired by the idea of being bounded together in the global Islamic society, the umma, and envisioned by theological doctrines in the Quran and the Hadith. The fundamental Islamic political doctrine says that religion (din) cannot be divorced from politics (dawla) and that the only true sovereignty and law are those of God. ${ }^{45}$ This principle is called din wa dawla or the unity of religion and state. Correspondingly, Muslim intellectuals and scholars perceive it differently, even stand in opposition, regarding the implementation of these doctrines. As a consequence, the understanding of these ideas in the Quran has resulted in either receiving or refusing secular ideologies like democracy and human rights, as well as questioning the compatibility of, say, Islam with democracy or Islam with human rights by Muslim politicians and activists. This leads to the rise of religion-based polities along with panIslamism and political Islam which encourage Muslims to be unified for common causes that mirror symbolic strength and communal identity. In the beginning of twenty first century, this global identity is reflected via internet and website, and even through engagement in civil society or may be terrorist networks. The widespread of such Islamic terrorist links along with their ideals to create a God-fearing Islamic polity, the caliphate under Shari'a laws, has generated a stereotype of the Islamic

${ }^{44}$ Husain al-Marsafi, 1881, cited in Fred Halliday, "The Politics of the Umma"..., 26.

45]. L. Esposito and J. O. Voll, "Islam and the West: Muslim Voices of Dialogue", Millennium Journal of International Studies, Vol. 29, No. 3 (2000), cited in Sara Silvestri, Does Islam Challenge European Identity? Continuum, Religious Roots of Contemporary European Identity, Data Standards Ltd, Somerset, 2007, 22. 
umma, and thus suspected to endanger sovereignty of the Western countries in particular the US and its alliances. ${ }^{46}$ Jama'a Islamiya in Southeast Asia and Al-Qaeda in the Middle East are evident to this case.

The phenomenon of political Islam or in other words Islamism has been defying the Western imperialism and Westphalian order immensely. Quoting Esposito and Voll, Shani emphasizes that throughout the Muslim world; Islamic oriented intellectuals have transformed Muslim political discourse in ways that are highly visible in both domestic politics and in international relations. ${ }^{47}$ Here, the ultimate goal of political Islam is to re-manage state power in Islamic states based on hakimiyyat Allah or God's rule' intended to found nizam Islami or Islamic governmental system using shari'a law. ${ }^{48}$ It is, therefore, a fundamental attachment not the watan (homeland) but to the umma or community of believers, all made equal in their submission to Allah. ${ }^{49}$

Islamic world (al-'alam al-Islami), once it has been imagined as united umma, would emerge at the center of popular imagination of the dark history of the Western occupation over the Muslim countries. Consider this example. After wars in Iraq, Bosnia, Kashmir, and Afghanistan, Usama Bin Laden conveyed his message to Muslims all over the world

\footnotetext{
${ }^{46}$ Sara Silvestri, Does Islam Challenge European Identity? Continuum, Religious Roots of Contemporary European Identity, Data Standards Ltd, Somerset, 2007, 22-23.

${ }^{47}$ J. L. Esposito and J. O. Voll, "Islam and the West: Muslim Voices of Dialogue", Millennium Journal of International Studies, Vol. 29, No. 3 (2000), 613 cited in G. Shani, "A Revolt against the West: Politicized Religion and the International Order A Comparison of the Islamic Umma and the Sikh Qaum", Ritsumeikan Annual Review of International Studies, Vol.1 (2002), 21.

${ }^{48}$ Bassam Tibi, "Post-Bipolar Order in Crisis: The Challenge of Politicised Islam", Millennium: Journal of International Studies, Vol. 29, No. 3 (2000), 49-50, cited in G. Shani, "A Revolt against the West: Politicized Religion and the International Order A Comparison of the Islamic Umma and the Sikh Qaum", Ritsumeikan Annual Review of International Studies, Vol.1 (2002), 22.

${ }^{49}$ Castels, 1997, 15, cited in cited in G. Shani, "A Revolt against the West: Politicized Religion and the International Order A Comparison of the Islamic Umma and the Sikh Qaum", Ritsumeikan Annual Review of International Studies, Vol.1 (2002), 22.
} 
on 7 October 2001 about 80 years of humiliation and shame. For the West, Laden's statement was bias, but for the Muslim World it was obviously connoted to the 1992 abolition of the Ottoman caliphate. ${ }^{50}$

\section{The Sikh diaspora}

According to Shani, there are three inter-connected considerations in situating the Sikhs as the focus of analysis. The first consideration is the Sikhs should be deemed as followers of any other recognized religions in the world like Islam and Christianity. The second consideration is the Sikhs should be regarded as a nation along with its territories. The third consideration is the widespread of Sikhs all over the world should be seen as diaspora. Unlike the umma, in the case of the Sikh community, there is no obvious difference between nation and diapora or, say, between watan (homeland) in Punjab and territory in Khalsa Panth. ${ }^{51}$

The first consideration is on the acceptance of the Sikhs as followers of any other recognized religions in the world like Islam and Christianity. Sikhism as a system of belief comprises teachings and rituals available in its divine book called "the Guru Granth Shahib," compiled in a sacred script especially to the Sikhs gurumukhi in gurdwara, its holy place of worship. To become a good Sikh, one must be 'baptized,' and agree to perform the Khalsa Rahit or the ethics of sikhs. Afterwards, this baptized sikh called amritdhari has to declare to obey the tenth Guru, Gobind Singh, to perform the five symbols of the sikh identity namely kes (hair), kanga (a comb), kachh (knee-length breeces), kara (a steel bracelet on the right hand), and kirpan (a sword). ${ }^{52}$

\footnotetext{
${ }^{50}$ G.P. Makris, Islam in the Middle East: a Living Tradition, USA: Blackwell Publishing, 2007, 45.

${ }^{51} \mathrm{G}$. Shani, "A Revolt against the West: Politicized Religion and the International Order A Comparison of the Islamic Umma and the Sikh Qaum", Ritsumeikan Annual Review of International Studies, Vol.1 (2002), 24.

${ }^{52} \mathrm{Hew}$ McLeod, Who is a Sikh? The Problem of Sikh Identity, Oxford: Oxford University Press, 1989, 96, cited in Shani, "A Revolt against the West"..., 24.
} 
The second consideration is on the acknowledgment of the Sikhs as a nation along with its borders, referring to their homeland in Punjab India. Sikhism as a nation can be traced from the history of the Khalsa independence in 1699 from Mughal, British and Indian occupations. The formal language of the Sikhs is Punjabi as their homeland is the Punjab. As a political entity, Sikhs have their own parliament called the Shiromani Gurdwara Prabandhak Committee (SGPC). They also have a unique political party named the Shiromani Akali Dal (SAD). The function of SGPC is to accommodate the Sikhs' aspiration as well as to produce a sort of legislation in accordance with their issues and problems. The main of of SGPC is located in the Akal Takht, a center of their spiritual and temporal power. ${ }^{53}$

The third consideration is on the admission of rapid widespread of Sikhs all over the world as diaspora. As a matter of fact, the overall population of the Sikhs around the world accounted to around 16 and 17 million, ${ }^{54}$ but it has been reported that it is increasing significantly to 25 million nowadays. ${ }^{55}$ In the light of history, despite the fact that the existing population of Sikh worldwide was as a result of immigration process after British imperialism in India, the emergence of Sikh migration beyond South Asia can be found in ways of communication between Sikh Soldiers and British army during the nineteenth century. In addition, the independence of India together with the partition of the Punjab in 1947 had been influencing the increasing number of Sikh population inside India who supported the post war-Northern Indian migration to the UK. In Great Britain, they involved in Ramgharia Sikhs

\footnotetext{
${ }^{53} \mathrm{G}$. Shani, "A Revolt against the West"..., 25.

${ }^{54}$ Darshan Singh and Tatla, The Sikh Diaspora: The Search for Statehood, London: UCL Press, 1999, 11, cited in G. Shani, "A Revolt against the West"..., 27.

${ }^{55}$ See Wikipedia, the free encyclopedia, "Sikh," [online] available from <http:// en.wikipedia.org/wiki/Sikh\#cite_note-0> accessed on 10 April 2009.
} 
and in political shifts in the East Africa in the late 1970s. Nowadays, it has been reported that more than half of the global Sikh population has been living in the UK around 750,000, in Canada accounted to 278,400, and in the USA about 100,000 people. ${ }^{56}$

According to Shani, the existence of the Sikh community defies the global order in two ways. First, it challenges the justification of warfare, either by using force or violence, by the Indian State against the Punjab. ${ }^{57}$ The Sikhs in diaspora want the sovereign statehood of the Punjab by emphasizing their right of self-determination in their homeland, the Punjab. The separation of Pakistan (1947) and Bangladesh (1971) from India are evident to this case as it inspired the Sikhs to demand the partition of the Punjab as well. ${ }^{58}$

Second, by refusing the sovereign statehood of India and demanding the sovereignty of the Khalsa, the Sikh community defies the Westphalian global order thoroughly. Due to the fact that there are no certain borders put on the sovereignty of the Khalsa, it allows the Sikh political demands to be implemented in the current federal legislation within India. Here, the SGPC-Akali Dal complex plays an important role for solving the case of the Khalsa Panth. ${ }^{59}$

In Hinsley's view, sovereignty consists of both internal and external dimensions. On internal level, as Hinsley argues, sovereignty entails the idea that there is a final and absolute political authority in the political community. Conversely, on external level, he suggests, that political authority will never be there. ${ }^{60}$ In this sense, the Sikh commu-

\footnotetext{
${ }^{56}$ Wikipedia, the free encyclopedia, "Sikh," [online] available from <http://en.wikipedia.org/ wiki/Sikh\#cite_note-0> accessed on 10 April 2009.

${ }^{57}$ G. Shani, "A Revolt against the West'..., 28-29.

${ }^{58}$ Gurharpal Singh and Darshan Sing Tatla, Sikhs in Britain: The Making of Community, London: Zed Books Ltd., 2006, 20.

${ }^{59} \mathrm{G}$. Shani, "A Revolt against the West'..., 29.
} 
nity is deemed as sovereign because the Khalsa Panth had been a center of all political and spiritual power for the Sikhs. This is reflected in Hargobind, miri and piri, the twin swords of the sixth Guru, as a symbol of the concepts of temporal and spiritual sovereignty, and thus emerged in the form of the Golden Temple complex founded by the Akal Takht and Harimandir. In Sikh traditions, wearing both sacred swords, miri and piri, is a prerogative right of the Guru Gobind Sing, but then Gobind Sing awarded piri (a symbol of spiritual sovereignty) to the Guru Granth Shahib, and miri (a symbol of temporal sovereignty) by the Kirpan to the Khalsa Panth announcing the edicts of Raj Karega Khalsa. Here, the Khalsa shall govern, and thus automatically become sovereign. ${ }^{61}$

Many argue that globalization has been affecting the conception of the nation-state in that the borders between nations are obscure, while the people among nations are interconnected beyond space and distance. Scholte refers the term globalization as follows:

"[Globalization] is a set of technological processes affecting the world economy, telecommunications, information technology, travel, and growing economic interdependence between states and peoples that is altering our sense of time and space, and is creating the possibility that the world will become a single social space". ${ }^{62}$

However, Steven Krasner is not convinced that sovereignty is being influenced basically by globalization. ${ }^{63}$ In response to this skepticism,

${ }^{60}$ F.R. Hinsley, Sovereignty, Cambridge: Cambridge University Presscited, 1986, cited in G. Shani, "A Revolt against the West'..., 29.

${ }^{61} \mathrm{G}$. Shani, "A Revolt against the West'..., 29; see also Gurharpal Singh and Darshan Sing Tatla, Sikhs in Britain: The Making of Community..., 20.

${ }^{62}$ Scholte, 2000, cited in Scott M. Thomas, The Global Resurgence of Religion and the Transformation of International Relations: The Struggle for the Soul of the Twenty-First Century. New York: Palgrave MacMillan, 2005, 29.

${ }^{63}$ Steven Krasner, 1999: 34 cited in Scott M. Thomas, The Global Resurgence of Religion and the Transformation of International Relations: The Struggle for the Soul of the Twenty-First Century. New York: Palgrave MacMillan, 2005, 30. 
Shani asserts that the recent process of globalization has transformed the Westhphalian conception of territorialized sovereignty, and that transformation is still in progress. The Sikh Diaspora is evident to this case. ${ }^{64}$

In the case of Sikh Diaspora, the Sikhs utilize the internet to get in touch and express their sense of the global unity of all Sikhs, and get engaged in the politics of homeland, the Punjab. This can be seen on their websites ${ }^{65}$ in which the term genocide is stated obviously referring to the massacre of the Sikhs in India accounted to 250,000 people were dying in the last two decades. ${ }^{66}$

\section{Conclusion}

In this paper, it has been argued that the rises of trans-national religious communities like the Islamic umma and the Sikh qaum have undermined the Westphalian global order. Under secular ideology, the role of religion is marginalized from the public sphere, in particular, the domain of politics and religion is being obviously separated. This separation, according to both groups, is problematic. Accordingly, the emergence of Islamic and Sikh communities is considered by some liberal democratic countries like India as a peril to its state sovereignty. In Islamic doctrines, the Muslims hold a principle in din wa dawla, the unity of state and religion, while in Sikhism, the Sikhs have to trust miri and piri, the unification of religious and political institution.

Having compared, both Islamic umma and the Sikh qaum have some commonalities and differences. Their similarities lie in the fact that both religio-political communities are imagined in the sense that they are finite and sovereign. For Muslims, the basic principle of their

${ }^{64}$ Giorgio Shani, "Beyond Khalistan? Sikh Diasporic Identity and Critical International Theory", Sikh Formations, Vol. 1, No. 1 (2005), 67.

${ }^{65}$ See http:// www.burningpunjab.com., and http://and www. Khalistan.com.

${ }^{66} \mathrm{http}: / /$ www.burningpunjab.com., and http://and www. Khalistan.com. 
identity is not to the watan (homeland), but to the umma. For Sikhs, wherever they reside in diaspora, the Punjab remains their homeland.

Somewhere in this paper, it has been acknowledged that both the Muslim umma and the Sikh community had been experiencing the same thing. It was after the tragedy of $9 / 11$, the Muslims and the Sikhs were suspected to involve in many terrorist movements around the world. In the UK, for instance, two Sikh organizations, the international Sikh Youth Federation and the Babar Khalsa were put on the black-list of the twenty two international terrorist groups along with other Islamic terrorists by the British Home Secretary David Blunkett. ${ }^{67}$ For both Muslims and the Sikhs, it is a sort of political conspiracy to pressure them in their homeland.

\section{Bibliography}

Anderson, Benedict. Imagined Communities: Reflections on the Origin and Spread of Nationalism, revised edition. 1st ed. 1983. London: Verso, 1991.

Barkin, J. Samuel and Bruce Cronin, "The State and the Nation: Changing Norms and the Rules of Sovereignty in International Relations", International Organization, Vol. 48, No.1 (Winter 1994).

Dolan, C. In War We Trust: The Bush Doctrine and the Pursuits of Just War. Aldershot: Ashgate, 2005.

Esposito, J. L and Voll, J. O., "Islam and the West: Muslim Voices of Dialogue", Millennium Journal of International Studies, Vol. 29, No. 3 (2000).

${ }^{67}$ Darshan Singh Tatla, "Sikhs in Multicultural Societies", International Journal on Multicultural Societies, Vol.5, No.2 (2003), 186. 
Gayer, L., "The Globalization of Identity Politics: The Sikh Experience", May, 2002, available from <http://www.ceri-sciences-po.org>, accessed on 2 April 2009.

Gerth, Hans H and C. Wright Mills, (eds). From Max Weber: Essays in Sociology. New York: Oxford University Press, 1981.

Grillo, R., "Islam and Trans-nationalism", Journal of Ethnic and Migration Studies, Vol. 30, No. 5 (2004).

Halliday, F. Islam and the Myth of Confrontation. London: I.B. Tauris, 1995.

Halliday, Fred, "The Politics of the Umma: States and Community in Islamic Movements", Mediterranean Politics, Vol.7, No.3 (2002).

Haynes, J. An Introduction to International Relations and Religion. Harlow, Essex: Pearson Longman, 2007.

Hinsley, F.R. Sovereignty. Cambridge: Cambridge University Press, 1986.

Kaldor, M. Global Civil Society: An Answer to War. Cambridge: Polity, 2003.

Lewis, B., "The Roots of Muslim Rage", The Atlantic monthly (September 1990): 52-60.

Lipschultz, R., "Recontructing World Politics: The Emergence of Global Civil Society", Millennium, Vol. 21, No. 3 (1992).

Makris, G.P. Islam in the Middle East: a Living Tradition. USA: Blackwell Publishing, 2007.

McLeod, Hew. Who is a Sikh? The Problem of Sikh Identity. Oxford: Oxford University Press, 1989.

Mirdal, G. M., L. Ryynanen-Karjalainen. Migration and Transcultural Identities. European Science Foundation (ESF) Forward Look Report 2, 2004. 
Nye, J. Soft Power: The Means to Success in World Politics. Washington DC: Public Affairs, 2004.

Petito, F., Hatzopoulos, P. (ed.). Religion in International Relations: Towards a De-secularised Transnational Civil Society? The Return from Exile. New York: Palgrave, 2003.

Philpott, D., "The Challenge of September 11 to Secularism in International Relations", World Politics 55 (October 2000).

Shani, G., "A Revolt against the West': Politicized Religion and the International Order-A Comparison of the Islamic Umma and the Sikh Qaum", Ritsumeikan Annual Review of International Studies, Vol.1 (2002a).

Shani, G., "The Territorialization of Identity: Sikh Nationalism in the Diaspora", Studies in Ethnicity and Nationalism, Vol. 2, No. 1 (2002b).

Shani, G., "Towards a De-secularized Transnational Civil Society? Transnational Religious Actors and International Relations", paper presented at panel on 'Religion, Soft power and International Relations', SGIR Conference, Torino, September, 12-15 2007.available from <http://archive.sgir.eu/uploads/Shani-sgir_2007_(shani).pdf> accessed on 2 April 2009.

Shani, Giorgio, "Beyond Khalistan? Sikh Diasporic Identity and Critical International Theory", Sikh Formations, Vol. 1, No. 1 (2005).

Silvestri, Sara, "Does Islam Challenge European Identity?", Continuum, Religious Roots of Contemporary European Identity, Data Standards Ltd, Somerset, 2007.

Singh, Gurharpal and Darshan Sing Tatla. Sikhs in Britain: The Making of Community. London: Zed Books Ltd., 2006. 
Tatla, Darshan S., "Sikhs in Multicultural Societies", International Journal on Multicultural Societies, Vol.5, No.2 (2003).

Tatla, Darshan Singh. The Sikh Diaspora: The Search for Statehood. London: UCL Press, 1999.

Thomas, Scott M. The Global Resurgence of Religion and the Transformation of International Relations: The Struggle for the Soul of the Twenty-First Century. New York: Palgrave MacMillan, 2005.

Thomson, Janice E., "State Sovereignty in International Relations: Bridging the Gap between theory and Empirical Research", International Studies Quarterly, Vol.39 (1995).

Tibi, Bassam, "Post-Bipolar Order in Crisis: The Challenge of Politicised Islam", Millennium: Journal of International Studies, Vol. 29, No. 3 (2000).

Wikipedia, the free encyclopedia, the Sikh, [online] available from <http:/ /en.wikipedia.org/wiki/Sikh\#cite_note-0> accessed on 10 April 2009. 